\title{
History and Evolution of Liver Transplantation
}

\author{
Ayman Azzam \\ Alexandria University \\ Egypt
}

\section{Introduction}

Historically, in ancient civilization, man had already imagined changes in the morphology, structure and function of the human body. Egyptian and Greco-Roman mythology provided examples of the metamorphoses sung by Homer and Ovid, symbolic incarnations of the "comedie humaine" with its strength, weakness, vices and virtues. The liver has been the noble organ, the organ of life from time immemorial-liver in English, Leber in German, derived from the verb to live. An Indian legend from the $12^{\text {th }}$ century B.C recounts the power of Shiva, who xenotransplanted an elephant head onto a child induce the Indian god Gaesha.[1] In ancient China, Yue-Jen (407-310 B.B.) induced anesthesia lasting 3 days by "the absorption of extremely strong wine, opened up the chest of two soldiers and after examining them, exchanged their hearts and transplanted them". The first reference to the concept of organ transplantation and replacement for therapeutic purposes appears to be Hua-To (136 to 208 A.D.) who replaced diseased organs with healthy ones in patients under anesthesia induced with a mixture of Indian hemp.

Although attempts at transplantation date back to ancient times, the impetus for modern transplantation was World War II and Battle of Britain. Royal Air Force pilots often were severely burned when their planes crashed. The mortality rate associated with burns corresponds to the size of the area of the skin that has been injured and the survival rate can be improved if the burned skin is replaced. For this reason, British doctors, attempted skin transplantation from other human donors as a mode of therapy. However, these attempts were uniformly unsuccessful. The transplanted skin became necrotic and fell off over several days.[2] This problem led investigators in 1940s to study skin transplantation in animal models. It remained for Sir Peter Medawar in 1944 to establish that the failure of a skin graft to "take" was the result of a process later termed immunological rejection. [3] Later studies by Gowens in 1948 revealed that lymphocytes play a major role in transplant rejection.[4] In 1951, it was shown that cortisone therapy significantly prolonged survival of skin allograft.[5] In 1959, Schwartz and Dameshek reported drug-induced immune-tolerance using 6-mercaptopurine.[6] Later in 1961, Calne and Murray showed that azathioprine therapy suppressed the rejection reaction and prolonged allograft survival.[7]

Once clinicians were confident that adequate immunosuppression was available, solid organ transplantation for end stage organ disease entered its early investigative phase. This was not possible without the application of the principles of vascular anastomosis pioneered by Alexis Carrel in 1902, for which he was awarded the Nobel Prize for Medicine in 1912.[8] 
Further refinements in surgical techniques and suture materials have enabled Murray and his colleagues to perform the first successful kidney transplant in 1955.[9] This was a living donor transplant performed between identical twins. However, later attempts to perform renal transplantation when the donor and recipient were not genetically identical failed because no effective immunosuppressive therapy was available. From the early 1960s, a combination of azathioprine and corticosteroids was used with success to prevent graft rejection after kidney transplantation. In 1963, Woodraff described the immunosuppressive effect of antilymphocytic serum which destroyed the recipient active lymphocytes.[10] The success of kidney transplantation paved the way to think and perform liver transplantation for end-stage liver disease.

In 1955, Welch reported on his efforts to transplant an auxiliary liver into the right paravertebral gutter of non-immunosuppressed mongrel dogs.[11] In 1958, Francis Moore described the standard technique of canine liver orthotopic liver transplantation.[12] In 1963, Starzl attempted the first human orthotopic liver transplantation in a 3-years-old boy who suffered from biliary atresia, however, the patient died before the operation was completed.[13] Following this first unsuccessful attempt, the procedure evolved slowly and although his series remained largely unsuccessful, many of the technical principles that still guide liver transplantation were established. In 1967, Starzl and colleagues at the University of Colorado reported the first successful clinical liver transplantation.[14]

Between 1966 and 1973, Starzl and colleagues performed three chimpanzee-to-human xenotransplantation of liver as well.[15] There have been 12 cases of clinical xenotransplantation including four cases of champazee-to-human, seven cases of baboon-tohuman and one case of pig-to-human.[16]

In 1978, Roy Calne opened liver transplantation unit in Cambridge, UK, and performed the first liver transplantation in Europe and the second largest transplantation series in the world.[17] Until 1977, Starzl and Calne contributed the majority of performed liver transplantation worldwide.[18]

The first hetero-topic liver transplants in man were reported by Apsolon in 1965; however, the first long-term survivor with this technique was reported by Fortner in 1973.[19]

In 1984, Shaw et al introduced the venovenous bypass system at Pittsburg University, leading to better hemodynamic stability during the standard liver transplantation.[20]

At the same time, Broelsch et al.[21] in the USA and Bismuth et al.[22] in France performed independently the first reduced-size liver transplantation. Thereafter, Pichlmayr et al.[23] reported the first split liver transplantation 1988. Meanwhile, Tzakis et al. introduced the piggyback technique with preservation of the recipient's vena cava.[24] With the increasing number of the patients on the waiting list, transplantation of partial liver grafts from living donors evoluted to increase the donor pool. For this purpose, Broelsch et al. established the technique of segmental living donor liver transplantation (LDLT), and Strong et al. performed the first successful LDLT in 1989, implanting a left lateral segment into a pediatric patient.[25] In 1990, Broelsch et al. reported the first series of LDLT in the USA.[21] In 1991, the first domino liver transplantation using liver from donors affected by familial amyloidotic polyneuropathy type I was introduced by Holmgren at al.[26] In 1992, Belghiti and coworkers introduced a modified piggyback technique with a cavo-caval side-to-side 
anastomosis.[27] One year later, Hashikura and colleagues transplanted a left hepatic lobe into an adult recipient in 1993,[28] and Yamaoka et al. implanted a right lobe into a pediatric recipient.[29] In 1996, Lo et al. performed the first successful liver transplantation using an extended right lobe from a living donor for an adult recipient.[30] In 1998, Tzakis et al. introduced liver transplantation with cavo-portal hemitransposition in the presence of diffuse portal vein thrombosis.[31] In 2002, Cherqui et al. reported first donor hepatectomy by a full laparoscopic procedure in which a left lateral lobectomy was successfully performed for liver transplantation in a child.[32]

\section{Evolution of immunosuppression}

Rejection of the transplant remained a major problem until cyclosporine-A was discovered by Jean Borel.[33] The 1-year survival rate following liver transplantation was $30 \%$ to $50 \%$ prior to the discovery of cyclosporine-A,[34,35] however, after the introduction of cyclosporine-A, the 1-year and 3-year survival rates were $74 \%$ and $67 \%$ in the first 1000 recipients treated with cyclosporine-A at the University of Pittsburgh in the early 1980s.[36] After these good results, growth of liver transplantation was facilitated by the conclusion of the National Institute of Health Consensus Development Conference in 1983 that liver transplantation is not an experimental procedure but an effective therapy that deserves broader application.[34] Shortly thereafter, the first monoclonal antibody OKT3 was discovered by Cosimi in 1981 and proved effective in treating acute transplant rejection and was sometimes used along with cyclosporine-A based regimen as immunoprophylaxis especially in North American Centers or to treat steroid resistant graft rejection.[37] Since then, many new immunosuppressive agents were introduced. In 1990, Mycophenolate mofetil (MMF, CellCept) was introduced by University of Wisconsin and proved, in combination with cyclosporine-A, to further reduce the incidence of graft rejection episodes better than azathioprine with less toxic effects.[38] In the same year, Rapamycin (Sirolimus) was introduced.[39] It is like cyclosporine-A but it has a different mechanism of action. It inhibits lymphocyte proliferation through prevention of ligation of IL-2 to the IL-2 receptors.[40] In 1994, Ochiai in Japan introduced tacrolimus (FK506, Prograf) and proved to reduce the incidence of transplant rejection more than cyclosporine A. It is like cyclosporineA but hundred times more potent and is indicated in severe acute rejection resistant to standard immunosuppressive protocols and in chronic rejection.[41]

Greater understanding of the underlying liver disease, improved surgical and anaesthetic techniques, reliable immunosuppression and dependable postoperative care over the last few years have contributed towards improved results of liver transplantation. This success has resulted in a disproportionate increase in demand of liver transplantation and the appearance of a major problem of shortage of available donor organs, leading to a prolonged waiting times and high mortality on the waiting list.[42]

\section{The progress in liver transplantation with donor shortage}

The donor shortage together with the development of surgical skills of liver resections based on the knowledge of segmental anatomy of the liver described by Couinaud,[43] opened the door for innovative methods of transplantation including auxiliary liver transplantation, reduced-liver transplantation (RLT), split liver transplantation (SLT) and living donor liver 
transplantation (LDLT).[44,45] Also, The donor shortage had led to the evolution of hepatocyte and stem cells transplantation which will be the future in the liver transplantation.

\subsection{Auxiliary liver transplantation}

Auxiliary liver transplantation (ALTx) consists of either implanting a healthy liver graft placed heterotopically or orthotopically while leaving all or part of the native liver. This concept was originated from an experimental work of Welch in 1955.[46, 47]

The first auxiliary liver transplantation in human was performed by Absolon in 1964,[48] and it was till 1972 when an auxiliary transplantation truly prolonged a human life.[49] During the following two decades, ALTx was done solely in a heterotopic manner heterotopic auxiliary liver transplantation (HALTx), where a graft (usually partial) is placed below the un-resected native liver. The initial clinical results of HALTx were rather disappointing with a high rate of technical failure, probably due to inadequate portal perfusion of the graft and insufficient drainage of hepatic blood flow in an area of low pressure which had led to temporary abandonment of HALTx in the early 70s.[50-52]

Many efforts have been made ever since to improve post-transplant survival. Most notably, based upon the experiences in animal studies,[52-58] the contributions of Terpstra's group have improved the surgical techniques of HALTx with markedly increased post-HALTx survival rate.[58-63] Since 1980s', the concept of ALTx has further been extended by the introduction of a new approach -auxiliary partial orthotopic liver transplantation (APOLTx), where the left or the right lobe of the native liver is resected and replaced by an auxiliary graft.[64-71] The physiological position of the hepatic graft by this approach results in an optimal outflow pressure. Accumulating clinical results have shown a reduced incidence of post-transplant portal thrombosis.[65, 72, 73]

For certain types of non-cirrhotic metabolic disorders, such as type 1 Crigler-Najjar syndrome, urea cycle enzyme deficiencies, disorders of fatty acid metabolism, familial hypercholesterolemia, hemophilia and ornithine transcarbamylase deficiency, an auxiliary liver may correct the partial enzymatic deficiency responsible for the disease without the need to remove the otherwise normal native liver. $[65,66]$ A significant minority of patients with acute liver failure who fulfill the transplant criteria would have had complete morphological and functional recovery of their liver if they had not undergone orthotopic liver transplantation.[74] These considerations have led to the concept of auxiliary liver transplantation, which doesn't exclude the potential for spontaneous regeneration of the native liver and eventual withdrawal of immunosuppression drugs.[75-78]

In selected patient aged $<40$ years without hemodynamic instability, the use of $A B O$ compatible, non-steatotic grafts harvested from young donors with normal liver function, can restore normal liver function and prevent the occurrence of irreversible brain damage. After standard immunosuppression, the recovery of the native liver is assessed by biopsies, hepatobiliary scintigraphy and computed tomography. When there is evidence of sufficient regeneration of the native liver, immunosuppression can be discontinued progressively. Complete regeneration of the native liver can be observed in $>50 \%$ of patients, who can be withdrawn from immunosuppression. Therefore, the advantages of the auxiliary liver transplantation seem to balance with the potential inconvenience of this technique in 
selected patients.[79-81] ALTx also preserves the patient's native liver, which remains accessible for future gene transfer therapy.[82]

\subsection{Reduced-sized liver transplantation (RLT)}

It was first reported in 1984 by Bismuth, and involves ex-vivo resection of an adult cadaveric liver in order to create an appropriate sized liver graft for an infant or small child. It was introduced as a surgical solution for decreasing the pediatric liver transplant waiting list mortality using organs from donors much larger than the recipient, but does not increase the total number of livers available for transplantation. This is because the reduced-sized portion is not used and discarded.[22]

Initially, RLT was criticized because it disadvantaged adult patients awaiting liver transplantation and was to be associated with inferior results. The allegations regarding inferior graft and patient survival were proven wrong,[83-85] and several proponents of this technique actually reported a lower incidence of vascular complications since the caliber of the hepatic artery was larger than that seen in a pediatric donor.[86] Since this technique resulted in discarding the remaining portion of liver, it clearly had a negative impact on adult population awaiting liver transplantation, and for that reason, is rarely used today.

\subsection{Split liver transplantation (SLT)}

In 1988, Pichlmayer in Germany and Bismuth in France simultaneously performed split liver transplantation (SLT), an ex-vivo splitting of a cadaveric liver allowing transplantation to a pediatric recipient and one adult.[23, 87] Unlike RLT, SLT resulted in an increased number of organs in donor pool with each cadaveric liver giving rise to two functioning allografts. The initial results of SLT, reported by Broelsch,[21] had a high rate of graft failure with a survival rate of only $67 \%$ in children and $20 \%$ in adults receiving a split liver transplants. In addition, $35 \%$ of patients required retransplantation and more than a quarter had biliary complications.[22] More recently, in-situ SLT has provided patient and graft survival similar to that seen in whole cadaveric transplantation.[88-90] The practical feasibility of split-liver transplantation as well as the increased safety of conventional liver surgery suddenly opened up the idea of removing part of the liver from a living donor.

\subsection{Living donor liver transplantation (LDLT)}

This has been made possible by recent advances in hepatic surgery; first, improved understanding of the anatomy and the techniques of hepatic resections,[91] second, growing evidence that the operative risk of partial hepatectomy in a non-cirrhotic liver is extremely low,[92, 93] third, widespread success with RLT,[25, 83-85, 94] and fourth, the successful application of SLT.[95]

\subsubsection{LDLT in pediatrics}

LDLT was first introduced in pediatric population. In 1988, Raia in Brazil reported the first LDLT, establishing the technical feasibility of this procedure, yet both pediatric recipients died of complications.[96] Strong and colleagues subsequently reported the first successful pediatric LDLT using a left lobe graft from the child's mother.[25] Broelsch reported the first 
successful series of LDLT with an overall graft survival of $75 \%$ and patient survival of $85 \%$.[97] Furthermore, he was the first to report a prospective ethical analysis of this radical surgical innovation prior to performing their first LDLT.[98]

LDLT in children involves the removal of an adult donor left lateral segment (segment 2 and 3). Monosegment transplantation (segment 3) was introduced in Japan to solve the problem of "Large for size" grafts in small children.[99] The donor operation has been associated with a low and acceptable risk for complications. The donors being related to the recipients (parents), the risk for the donor is balanced by the great benefit to be received by the transplant recipient, as well as the donor's psychological benefit.

LDLT was initially restricted to children with chronic disease, in relatively stable condition, in order to avoid a major psychological pressure on the potential donor.[98] With larger experience, it was extended to emergency cases such as fulminant hepatic failure. Auxiliary transplantation, initially developed in this indication,[78] and in metabolic disorders,[100] could also be performed with a living donor liver.[101-104]

The continued shortage of cadaver livers in the face of growing list of recipients plus the advantages of LDLT have led to the introduction of LDLT in adults.

\subsubsection{Adult-to-adult LDLT}

The expansion of LDLT to the adult population began in the countries where the availability of deceased donors was scarce, and in some cases, totally unavailable.[105-107] The law for deceased organ retrieval was instituted in Japan in 1998, however, the lack of societal acceptance of organ retrieval from brain dead donors resulted in live donation being the main source of grafts for patients awaiting transplantation in Japan and other countries in Asia.[108]

On November 2, 1993, the Shinshu group performed the first successful adult-to-adult LDLT.[28] By June 2002, there were 433 adult LDLT cases recorded in European Liver Transplantation Regestery,[109] with 3 years graft and patient survival rate of $65 \%$ and $68 \%$ respectively. According to the United Network for Organ Sharing (UNOS), 731 adult LDLT cases have been performed in the United States by October 2001. The 3 years graft survival was $47 \%$ between 1998 and $1999(n=156)$ but it improved significantly to 61\% between July 1999 and June 2001 (n=285).[110] According to the Japanese Liver Transplantation Society, 1063 adult LDLT procedures were performed in Japan by the end of 2002. The 5 years survival rates were $83 \%$ in children and $69 \%$ in adults.[111] The lesser outcome in adults compared to that in children indicates that problems remain in adult LDLT.

In LDLT, donor safety must be assured. This may be achieved by optimizing graft size to ensure safety of both donor and recipient, technical expertise in liver procurement from the donor as well as ethical problems of using non-related live donors. As regarding the optimum size of the graft, it was found that, a graft volume of $>40 \%$ of the recipient standard liver volume is necessary,[112] while for the living donor the remnant liver mass must be more than $30 \%$ of the whole liver.[113] The term "standard liver volume" has become a key concept in LDLT and it has been estimated using the following formula:[114]

Standard liver volume $(\mathrm{SV})$ in $\mathrm{ml}=706.2 \times\left(\right.$ body surface area $\left.\left[\mathrm{m}^{2}\right]\right)+2.4$. 
In order to obtain the optimum graft size in adult-to-adult living donor transplantation, many graft types has been introduced. The strategy of selection of left or right liver graft is influenced by the patient's preoperative condition as patient with advanced liver disease require a larger liver mass.[115] The model for end-stage liver disease (MELD) score could become a satisfactory criterion for differentiating between high and low-risk patients and therefore determine the type of graft to use.[116] In the initial adult LDLT procedures only a left liver graft was used. In 1998, the Shinshu group reported satisfactory results using a left liver graft in 13 patients.[107] To cover wide range of recipient body weight, the right lobe graft was introduced in 1998 in Kyoto university.[117] In the same year, the University of Colorado group also introduced the right liver graft in adult LDLT,[118] the group performed 80 adult LDLT. In the first 10 cases, the right lobe graft was procured without the middle hepatic vein (MHV), 3 grafts were lost. As a result, the group included the MHV in the right lobe graft in the subsequent 70 cases. No graft loss was experienced.[119] The reason may be due to the prevention of congestion of the anterior segment of the right lobe which is drained by the MHV. However, the right lobe graft including the MHV was first introduced by the Hong Kong group in 1996.[106] In this situation, the volume of the remnant liver should be at least greater than $30 \%$ and the anatomy of vein 4 must be precisely evaluated before this procedure is accepted. However, the outcome of initial 8 donors and recipients were not without complications, one recipient died and the recipients as well as the donors experienced high morbidity.[106] The next 92 patients subsequently received extended right liver grafts (right lobe graft including the MHV) with the following innovations: elimination of venovenous bypass from the routine protocol, preservation of segment 4 venous drainage for donors, venoplasty of MHV and right hepatic vein (RHV) into a single orifice for better venous return and easy vein reconstruction in recipients and preservation of the blood supply to the right hepatic ducts. Over time the mortality rate of recipient decrease from $16 \%$ in the initial 50 cases to $0 \%$ in more recent patients.[120]

Lee, aggressively reconstructed the MHV tributaries in right liver grafts without the MHV trunk and named this type of graft a modified right lobe graft.[121] Ghobrial, also recommended reconstruction of the MHV tributary veins when the RHV in the graft was $<1.5 \mathrm{~cm}$ in diameter.[90] All MHV tributaries with a size $>5 \mathrm{~mm}$ should be preserved during donor hepatectomy and reconstructed with autogenous interposition vein grafts.[122]

Right hepatectomy imposes an increased surgical risk on the donor due to the reduced residual liver volume. A recent report indicated that in $25 \%$ of potential donors, the right liver had an estimated volume of $>70 \%$ of the whole.[123] Since safe donation was possible only when estimated residual liver volume was $>30 \%$, right hepatectomy is not possible for some potential donors. The University of Tokyo group was the first to design the right lateral sector graft consisting of segment 6 and 7 in those donors with right livers over $70 \%$ of liver volume and the estimated volume of the right lateral segments is greater than that of the left liver and at the same time $>40 \%$ of the recipient's standard liver volume.[124] Between January 2000 and April 2001, 6 of 32 adult-to-adult LDLT with a right lateral sector graft were performed. The postoperative course was uneventful in all donors and all recipients survived the operation.[125]

Lee et al, were the first to devise dual grafts from 2 living donors.[126] Most commonly, both donors donate the left liver or left lateral segment. The first left liver graft is orthotopically implanted in the original left position, the second left liver graft is rotated 180 
degrees and positioned heterotopically in the right upper quadrant fossa. Because the bile duct is now located behind the portal vein and hepatic artery, bile duct reconstruction is necessary before reconstruction of vessels. An interposition vein graft might be necessary for the reconstruction of the hepatic or portal vein. By the end of 2003, this technique was used in 93 patients with satisfactory results. However the procedure has limited appeal due to the high requirements of economic and medical resources including 3 operating rooms and 3 surgical teams working simultaneously.[127]

\section{Hepatocyte and stem cells transplantation}

Additional approaches, as therapeutic alternative in attempt to reduce the significant mortality in the waiting list for liver transplantation is hepatocyte transplantation. A number of experiments have shown the feasibility of total liver parenchymal cell replacement by transplanted hepatocytes.[128-132] Hepatocyte transplantation might be able to bridge a period needed for regeneration of the acute liver failure patient's own liver or stretch the waiting time for a suitable liver donation. Although the first animal experiments with this technique began in 1967 [133], it was first applied in humans only in 1992.[134] Isolated Hepatocyte transplantation has long been recognized as a potential treatment for life-threatening liver disease. The basis for proceeding with clinical trials has been provided by extensive laboratory work in animal models.[135-140] The most important advantage of this treatment compared to liver transplantation, is its simplicity, since no surgery is required for cell implantation. The cell transplantation has been used for, temporary metabolic support of patients in end-stage liver failure awaiting whole-organ transplantation, as method to support liver function and facilitate the regeneration of the native liver in cases of fulminant hepatic failure, and in a manner similar to gene therapy as a form of "cellular therapy" for patients with genetic defects in vital liver functions. The patients can be treated by the infusion of $10^{7}-10^{10}$ allogenic hepatocytes, obtained from adult cadaveric livers, into the splenic artery or portal vein.[141] The main obstacle to wider usage of hepatocyte transplantation is the rapid elimination of the transplanted hepatocytes by recipient macrophages.[142]

Alternatives to the transplantation of allogenic human hepatocytes include the transplantation of hepatocytes derived from fetal, adult, or embryonic stem cells, engineered immortalized cells, or hepatocytes derived from other animal species.[143] Stem cells are one of the best approaches to obtaining cell stores. This approach can be used for clinical treatment by selecting small cell population that could effectively repopulate the host liver.[144]

\section{References}

[1] Calne R. The history and development of organ transplantation: biology and rejection. Bailliere's clinical gastroenterology. 1994 Sep;8(3):389-97.

[2] Hansen TH, Carreno BM, Sachs DH. The major histocompatibility complex. In: Paul WE, ed. Fundamental immunology. New York: Raven Press 1993:577-628.

[3] Medawar P. The behavior and fate of skin autografts and skin homografts in rabbits. J Anat. 1944;78:176.

[4] Gowen JW. Inheritance of immunity in animals. Ann Rev Microbial. 1948;2:215.

[5] Billingham RE, Krohn PL, Medawar PB. Effect of cortisone on survival of skin homografts in rabbits. Br Med J. 1951 May 26;4716:1157-63. 
[6] Schwartz R, Stack J, Dameshek W. Effect of 6-mercaptopurine on antibody production. Proc Soc Exp Biol Med. 1958 Oct;99(1):164-7.

[7] Calne RY, Murray JE. Inhibition of the rejection of renal homografts in dogs by Burroughs Wellcome 57-322. Surg Forum. 1961;12:118-20.

[8] Carrel A. La technique opertoire des anastomoses vasculaires et la transplantation des visceres. Lyon Med. 1902;98:859.

[9] Murray JE, Merrill JP, et al. Renal homotransplantation in identical twins. Surg Forum. 1955;6:432.

[10] Woodruff MF, Anderson NA. Effect of Lymphocyte Depletion by Thoracic Duct Fistula and Administration of Antilymphocytic Serum on the Survival of Skin Homografts in Rats. Nature. 1963 Nov 16;200:702.

[11] Welch CS. A note on transplantation of the whole liver in dogs. Transplant Bull. 1955;2:54.

[12] Moore FD, Wheele HB, Demissianos HV, Smith LL, Balankura O, Abel K, et al. Experimental whole-organ transplantation of the liver and of the spleen. Ann Surg. 1960 Sep;152:374-87.

[13] Starzl TE, Marchioro TL, Vonkaulla KN, Hermann G, Brittain RS, Waddell WR. Homotransplantation of the Liver in Humans. Surgery, gynecology \& obstetrics. 1963 Dec;117:659-76.

[14] Starzl TE, Groth CG, Brettschneider L, Penn I, Fulginiti VA, Moon JB, et al. Orthotopic homotransplantation of the human liver. Ann Surg. 1968 Sep;168(3):392-415.

[15] Starzl TE, Marchioro TL, Porter KA, Iwasaki Y, Cerilli GJ. The use of heterologous antilymphoid agents in canine renal and liver homotransplantation and in human renal homotransplantation. Surgery, gynecology \& obstetrics. 1967 Feb;124(2):3018.

[16] Taniguchi S, Cooper DKC (1997). Clinical xenotransplantation: a brief review of the world experience. In: Cooper DKC, Kemp E, Platt JL, White DJD (eds) Xenotransplantation: the transplantation of organs between species. Springer, Berlin Heidelberg New York, p779.

[17] Calne RY, White DJ, Rolles K, Smith DP, Herbertson BM. Prolonged survival of pig orthotopic heart grafts treated with cyclosporin A. Lancet. 1978 Jun 3;1(8075):1183-5.

[18] Eghtesad B, Kadry Z, Fung J. Technical considerations in liver transplantation: what a hepatologist needs to know (and every surgeon should practice). Liver Transpl. 2005 Aug;11(8):861-71.

[19] Fortner JG, Kinne DW, Shiu MH, Howland WS, Kim DK, Castro EB, et al. Clinical liver heterotopic (auxiliary) transplantation. Surgery. 1973 Nov;74(5):739-51.

[20] Shaw BW, Jr., Martin DJ, Marquez JM, Kang YG, Bugbee AC, Jr., Iwatsuki S, et al. Venous bypass in clinical liver transplantation. Ann Surg. 1984 Oct;200(4):524-34.

[21] Broelsch CE, Emond JC, Whitington PF, Thistlethwaite JR, Baker AL, Lichtor JL. Application of reduced-size liver transplants as split grafts, auxiliary orthotopic grafts, and living related segmental transplants. Ann Surg. 1990 Sep;212(3):368-75; discussion 75-7.

[22] Bismuth H, Houssin D. Reduced-sized orthotopic liver graft in hepatic transplantation in children. Surgery. 1984 Mar;95(3):367-70.

[23] Pichlmayr R, Ringe B, Gubernatis G, Hauss J, Bunzendahl H. [Transplantation of a donor liver to 2 recipients (splitting transplantation)--a new method in the further development of segmental liver transplantation]. Langenbecks Arch Chir. 1988;373(2):127-30. 
[24] Tzakis A, Todo S, Starzl TE. Orthotopic liver transplantation with preservation of the inferior vena cava. Ann Surg. 1989 Nov;210(5):649-52.

[25] Strong RW, Lynch SV, Ong TH, Matsunami H, Koido Y, Balderson GA. Successful liver transplantation from a living donor to her son. N Engl J Med. 1990 May 24;322(21):1505-7.

[26] Holmgren G, Steen L, Ekstedt J, Groth CG, Ericzon BG, Eriksson S, et al. Biochemical effect of liver transplantation in two Swedish patients with familial amyloidotic polyneuropathy (FAP-met30). Clin Genet. 1991 Sep;40(3):242-6.

[27] Belghiti J, Panis Y, Sauvanet A, Gayet B, Fekete F. A new technique of side to side caval anastomosis during orthotopic hepatic transplantation without inferior vena caval occlusion. Surgery, gynecology \& obstetrics. 1992 Sep;175(3):270-2.

[28] Hashikura Y, Makuuchi M, Kawasaki S, Matsunami H, Ikegami T, Nakazawa Y, et al. Successful living-related partial liver transplantation to an adult patient. Lancet. 1994 May 14;343(8907):1233-4.

[29] Yamaoka Y, Washida M, Honda K, Tanaka K, Mori K, Shimahara Y, et al. Liver transplantation using a right lobe graft from a living related donor. Transplantation. 1994 Apr 15;57(7):1127-30.

[30] Lo CM, Fan ST, Liu CL, Lo RJ, Lau GK, Wei WI, et al. Extending the limit on the size of adult recipient in living donor liver transplantation using extended right lobe graft. Transplantation. 1997 May 27;63(10):1524-8.

[31] Tzakis AG, Kirkegaard P, Pinna AD, Jovine E, Misiakos EP, Maziotti A, et al. Liver transplantation with cavoportal hemitransposition in the presence of diffuse portal vein thrombosis. Transplantation. 1998 Mar 15;65(5):619-24.

[32] Cherqui D, Soubrane O, Husson E, Barshasz E, Vignaux O, Ghimouz M, et al. Laparoscopic living donor hepatectomy for liver transplantation in children. Lancet. 2002 Feb 2;359(9304):392-6.

[33] Borel JF, Baumann G, Chapman I, Donatsch P, Fahr A, Mueller EA, et al. In vivo pharmacological effects of ciclosporin and some analogues. Adv Pharmacol. 1996;35:115-246.

[34] National Institutes of Health Consensus Development Conference Statement: liver transplantation--June 20-23, 1983. Hepatology (Baltimore, Md. 1984 Jan-Feb;4(1 Suppl):107S-10S.

[35] Scharschmidt BF. Human liver transplantation: analysis of data on 540 patients from four centers. Hepatology (Baltimore, Md. 1984 Jan-Feb;4(1 Suppl):95S-101S.

[36] Iwatsuki S, Starzl TE, Todo S, Gordon RD, Esquivel CO, Tzakis AG, et al. Experience in 1,000 liver transplants under cyclosporine-steroid therapy: a survival report. Transplant Proc. 1988 Feb;20(1 Suppl 1):498-504.

[37] Cosimi AB, Colvin RB, Burton RC, Rubin RH, Goldstein G, Kung PC, et al. Use of monoclonal antibodies to T-cell subsets for immunologic monitoring and treatment in recipients of renal allografts. N Engl J Med. 1981 Aug 6;305(6):308-14.

[38] Barry JM. Immunosuppressive drugs in renal transplantation. A review of the regimens. Drugs. 1992 Oct;44(4):554-66.

[39] Strepkowski SM. Sirolimus, a potent new immunosuppressive drug for organ transplantation. Ann Transplant. 1996;1 (3):19-25.

[40] Klagehpour K, Pyronnet S, Gingras AC, al e. Translational homeostasis: eukaryotic translation initiation factor $4 \mathrm{E}$ control of $4 \mathrm{E}-$ binding protien 1 and p70 s6 kinase activities. Mol Cell Biol. 1999;19:4302-20. 
[41] Takada Y, Ueda M, Ishikawa Y, Fujimoto Y, Miyauchi H, Ogura Y, et al. End-to-side portocaval shunting for a small-for-size graft in living donor liver transplantation. Liver Transpl. 2004 Jun;10(6):807-10.

[42] Modan B, Shpilberg O, Baruch Y, Sikuler E, Anis E, Ashur Y, et al. The need for liver transplantation: a nationwide estimate based on consensus review. Lancet. 1995 Sep 9;346(8976):660-2.

[43] Couinaud C. Le foie. Etudes anatomiques et chirurgicales. Paris: Masson. 1957.

[44] Smith B. Segmental liver transplantation from a living donor. J Pediatr Surg. 1969 Feb;4(1):126-32.

[45] Dagradi A, Marzoli GP, Radin S, Sussi PL, Dagradi V, Zannini M, et al. [Possibilities of sectional liver transplantation in man]. Langenbecks Arch Chir. 1968;322:533-7.

[46] Marchioro TL, Porter KA, Dickinson TC, Faris TD, Starzi TE. Physiologic Requirements for Auxiliary Liver Homotransplantation. Surgery, gynecology \& obstetrics. 1965 Jul;121:17-31.

[47] Nagashima I, Bergmann L, Schweizer R. How can we share the portal blood inflow in auxiliary partial heterotopic liver transplantation without portal hypertension? Surgery. 1994 Jul;116(1):101-6.

[48] Zhao D, Zimmermann A, Kuznetsova LV, Wheatley AM. Regression of bile duct damage and bile duct proliferation in the non-rearterialized transplanted rat liver is associated with spontaneous graft rearterialization. Hepatology (Baltimore, Md. 1995 May;21(5):1353-60.

[49] Svensson G, Naredi P, Hafstrom L, Tufveson G. Quantitative measurements of collateral arterial blood flow in nonarterialized rat liver grafts. Transpl Int. 1994;7(2):136-9.

[50] Howden B, Jablonski P, Grossman H, Marshall VC. The importance of the hepatic artery in rat liver transplantation. Transplantation. 1989 Mar;47(3):428-31.

[51] Sumimoto R, Shinomiya T, Yamaguchi A. Influence of hepatic arterial blood flow in rats with liver transplants. Examination of donor liver-derived serum class I MHC antigen in rats with liver transplants with or without hepatic arterial reconstruction. Transplantation. 1991 May;51(5):1138-9.

[52] Post S, Menger MD, Rentsch M, Gonzalez AP, Herfarth C, Messmer K. The impact of arterialization on hepatic microcirculation and leukocyte accumulation after liver transplantation in the rat. Transplantation. 1992 Nov;54(5):789-94.

[53] Taub R. Liver regeneration 4: transcriptional control of liver regeneration. Faseb J. 1996 Mar;10(4):413-27.

[54] Gentile JM, Grace JT, Jr. A cell growth stimulating factor in partially hepatectomized rat serum. Surgical forum. 1968;19:62-3.

[55] Morley CG, Kingdon HS. The regulation of cell growth. I. Identification and partial characterization of a DNA synthesis stimulating factor from the serum of partially hepatectomized rats. Biochimica et biophysica acta. 1973 May 10;308(2):260-75.

[56] Michalopoulos GK, DeFrances MC. Liver regeneration. Science (New York, NY. 1997 Apr 4;276(5309):60-6.

[57] LaBrecque D. Liver regeneration: a picture emerges from the puzzle. The American journal of gastroenterology. 1994 Aug;89(8 Suppl):S86-96.

[58] Moolten FL, Oakman NJ, Bucher NL. Accelerated response of hepatic DNA synthesis to partial hepatectomy in rats pretreated with growth hormone or surgical stress. Cancer research. 1970 Sep;30(9):2353-7. 
[59] Zhao D, Zimmermann A, Wheatley AM. Morphometry of the liver after liver transplantation in the rat: significance of an intact arterial supply. Hepatology (Baltimore, Md. 1993 Feb;17(2):310-7.

[60] Burdelski M, Rogiers X. Liver transplantation in metabolic disorders. Acta gastroenterologica Belgica. 1999 Jul-Sep;62(3):300-5.

[61] Kren BT, Trembley JH, Fan G, Steer CJ. Molecular regulation of liver regeneration. Annals of the New York Academy of Sciences. 1997 Dec 31;831:361-81.

[62] Morsiani E, Aleotti A, Ricci D. Haemodynamic and ultrastructural observations on the rat liver after two-thirds partial hepatectomy. Journal of anatomy. 1998 May;192 ( Pt 4):507-15.

[63] Zhang XK, Gauthier T, Burczynski FJ, Wang GQ, Gong YW, Minuk GY. Changes in liver membrane potentials after partial hepatectomy in rats. Hepatology (Baltimore, Md. 1996 Mar;23(3):549-51.

[64] Neuschwander-Tetri BA, Nicholson C, Wells LD, Tracy TF, Jr. Cholestatic liver injury down-regulates hepatic glutathione synthesis. The Journal of surgical research. 1996 Jul 1;63(2):447-51.

[65] Chandler JG, Lee S, Krubel R, Rosen H, Nakaji NT, Orloff MJ. The inter-liver competition and portal blood in regeneration of auxiliary liver transplants. Surgical forum. 1971;22:341-3.

[66] Shaw BW, Jr. Auxiliary liver transplantation for acute liver failure. Liver Transpl Surg. 1995 May;1(3):194-200.

[67] Wondergem R, Potter VR. A new protocol for studying the early events during liver regeneration. Life sciences. 1978 Oct 16;23(15):1565-75.

[68] Schenk DB, Hubert JJ, Leffert HL. Use of a monoclonal antibody to quantify $(\mathrm{Na}+, \mathrm{K}+)-$ ATPase activity and sites in normal and regenerating rat liver. The Journal of biological chemistry. 1984 Dec 10;259(23):14941-51.

[69] Moule SK, McGivan JD. Regulation of the plasma membrane potential in hepatocytes-mechanism and physiological significance. Biochimica et biophysica acta. 1990 Oct 8;1031(3):383-97.

[70] Kelm M, Feelisch M, Deussen A, Strauer BE, Schrader J. Release of endothelium derived nitric oxide in relation to pressure and flow. Cardiovascular research. 1991 Oct;25(10):831-6.

[71] Feelisch M, Ostrowski J, Noack E. On the mechanism of NO release from sydnonimines. Journal of cardiovascular pharmacology. 1989;14 Suppl 11:S13-22.

[72] Schoen JM, Wang HH, Minuk GY, Lautt WW. Shear stress-induced nitric oxide release triggers the liver regeneration cascade. Nitric Oxide. 2001;5(5):453-64.

[73] Lambotte L, Saliez A, Triest S, Tagliaferri EM, Barker AP, Baranski AG. Control of rate and extent of the proliferative response after partial hepatectomy. The American journal of physiology. 1997 Oct;273(4 Pt 1):G905-12.

[74] Wolf HK, Michalopoulos GK. Hepatocyte regeneration in acute fulminant and nonfulminant hepatitis: a study of proliferating cell nuclear antigen expression. Hepatology (Baltimore, Md. 1992 Apr;15(4):707-13.

[75] Moritz MJ, Jarrell BE, Munoz SJ, Maddrey WC. Regeneration of the native liver after heterotopic liver transplantation for fulminant hepatic failure. Transplantation. 1993 Apr;55(4):952-4.

[76] Moritz MJ, Jarrell BE, Armenti V, Radomski J, Carabasi RA, Zeitoun G, et al. Heterotopic liver transplantation for fulminant hepatic failure--a bridge to recovery. Transplantation. 1990 Sep;50(3):524-6. 
[77] Gubernatis G, Pichlmayr R, Kemnitz J, Gratz K. Auxiliary partial orthotopic liver transplantation (APOLT) for fulminant hepatic failure: first successful case report. World J Surg. 1991 Sep-Oct;15(5):660-5; discussion 5-6.

[78] Boudjema K, Jaeck D, Simeoni U, Bientz J, Chenard MP, Brunot P. Temporary auxiliary liver transplantation for subacute liver failure in a child. Lancet. 1993 Sep 25;342(8874):778-9.

[79] Durand F, Belghiti J, Handra-Luca A, Francoz C, Sauvanet A, Marcellin P, et al. Auxiliary liver transplantation for fulminant hepatitis B: results from a series of six patients with special emphasis on regeneration and recurrence of hepatitis B. Liver Transpl. 2002 Aug;8(8):701-7.

[80] Belghiti J, Sommacale D, Dondero F, Zinzindohoue F, Sauvanet A, Durand F. Auxiliary liver transplantation for acute liver failure. HPB (Oxford). 2004;6(2):83-7.

[81] Chenard-Neu MP, Boudjema K, Bernuau J, Degott C, Belghiti J, Cherqui D, et al. Auxiliary liver transplantation: regeneration of the native liver and outcome in 30 patients with fulminant hepatic failure--a multicenter European study. Hepatology (Baltimore, Md. 1996 May;23(5):1119-27.

[82] Nakazawa H, Genka C, Fujishima M. Pathological aspects of active oxygens/free radicals. The Japanese journal of physiology. 1996 Feb;46(1):15-32.

[83] Emond JC, Whitington PF, Thistlethwaite JR, Alonso EM, Broelsch CE. Reduced-size orthotopic liver transplantation: use in the management of children with chronic liver disease. Hepatology (Baltimore, Md. 1989 Nov;10(5):867-72.

[84] Ryckman FC, Flake AW, Fisher RA, Tchervenkov JI, Pedersen SH, Balistreri WF. Segmental orthotopic hepatic transplantation as a means to improve patient survival and diminish waiting-list mortality. J Pediatr Surg. 1991 Apr;26(4):422-7; discussion 7-8.

[85] Otte JB, de Ville de Goyet J, Sokal E, Alberti D, Moulin D, de Hemptinne B, et al. Size reduction of the donor liver is a safe way to alleviate the shortage of size-matched organs in pediatric liver transplantation. Ann Surg. 1990 Feb;211(2):146-57.

[86] Houssin D, Soubrane O, Boillot O, Dousset B, Ozier Y, Devictor D, et al. Orthotopic liver transplantation with a reduced-size graft: an ideal compromise in pediatrics? Surgery. 1992 May;111(5):532-42.

[87] Bismuth H, Morino M, Castaing D, Gillon MC, Descorps Declere A, Saliba F, et al. Emergency orthotopic liver transplantation in two patients using one donor liver. Br J Surg. 1989 Jul;76(7):722-4.

[88] Rogiers X, Malago M, Gawad K, Jauch KW, Olausson M, Knoefel WT, et al. In situ splitting of cadaveric livers. The ultimate expansion of a limited donor pool. Ann Surg. 1996 Sep;224(3):331-9; discussion 9-41.

[89] Busuttil RW, Goss JA. Split liver transplantation. Ann Surg. 1999 Mar;229(3):313-21.

[90] Goss JA, Yersiz H, Shackleton CR, Seu P, Smith CV, Markowitz JS, et al. In situ splitting of the cadaveric liver for transplantation. Transplantation. 1997 Sep 27;64(6):871-7.

[91] Bismuth H, Castaing D, Garden OJ. Segmental surgery of the liver. Surg Annu. 1988;20:291-310.

[92] Iwatsuki S, Todo S, Starzl TE. Excisional therapy for benign hepatic lesions. Surgery, gynecology \& obstetrics. 1990 Sep;171(3):240-6.

[93] Bismuth H, Houssin D, Michel F. [Operative risk in hepatectomies. Experience with 154 hepatectomies]. Chirurgie. 1983;109(4):342-8.

[94] Kalayouglu M, D' Alessandro AM, Sollinger HW, et al. Experience with reduced-size liver transplantation. Surgery, gynecology \& obstetrics. 1990;171:139-47. 
[95] Emond JC, Whitington PF, Thistlethwaite JR, Cherqui D, Alonso EA, Woodle IS, et al. Transplantation of two patients with one liver. Analysis of a preliminary experience with 'split-liver' grafting. Ann Surg. 1990 Jul;212(1):14-22.

[96] Raia S, Nery JR, Mies S. Liver transplantation from live donors. Lancet. 1989 Aug 26;2(8661):497.

[97] Broelsch CE, Whitington PF, Emond JC, Heffron TG, Thistlethwaite JR, Stevens L, et al. Liver transplantation in children from living related donors. Surgical techniques and results. Ann Surg. 1991 Oct;214(4):428-37; discussion 37-9.

[98] Singer PA, Siegler M, Whitington PF, Lantos JD, Emond JC, Thistlethwaite JR, et al. Ethics of liver transplantation with living donors. N Engl J Med. 1989 Aug 31;321(9):620-2.

[99] Kasahara M, Kiuchi T, Haga H, Uemoto S, Uryuhara K, Fujimoto Y, et al. Monosegmental living-donor liver transplantation for infantile hepatic hemangioendothelioma. J Pediatr Surg. 2003 Jul;38(7):1108-11.

[100] Whitington PF, Emond JC, Heffron T, Thistlethwaite JR. Orthotopic auxiliary liver transplantation for Crigler-Najjar syndrome type 1. Lancet. 1993 Sep 25;342(8874):779-80.

[101] Emond JC, Heffron TG, Kortz EO, Gonzalez-Vallina R, Contis JC, Black DD, et al. Improved results of living-related liver transplantation with routine application in a pediatric program. Transplantation. 1993 Apr;55(4):835-40.

[102] Inomata Y, Kiuchi T, Kim I, Uemoto S, Egawa H, Asonuma K, et al. Auxiliary partial orthotopic living donor liver transplantation as an aid for small-for-size grafts in larger recipients. Transplantation. 1999 May 27;67(10):1314-9.

[103] Yazaki M, Ikeda S, Takei Y, Yanagisawa N, Matsunami H, Hashikura Y, et al. Complete neurological recovery of an adult patient with type II citrullinemia after living related partial liver transplantation. Transplantation. 1996 Dec 15;62(11):1679-84.

[104] Kasahara M, Kiuchi T, Uryuhara K, Ogura Y, Takakura K, Egawa H, et al. Treatment of ornithine transcarbamylase deficiency in girls by auxiliary liver transplantation: conceptual changes in a living-donor program. J Pediatr Surg. 1998 Dec;33(12):1753-6.

[105] Lo CM, Lo RJ, Lai CL, Fan ST, Wong J. Liver transplantation from cadaveric and living donors. Transplant Proc. 1996 Jun;28(3):1659-60.

[106] Lo CM, Fan ST, Liu CL, Wei WI, Lo RJ, Lai CL, et al. Adult-to-adult living donor liver transplantation using extended right lobe grafts. Ann Surg. 1997 Sep;226(3):261-9; discussion 9-70.

[107] Kawasaki S, Makuuchi M, Matsunami H, Hashikura Y, Ikegami T, Nakazawa Y, et al. Living related liver transplantation in adults. Ann Surg. 1998 Feb;227(2):269-74.

[108] Tanaka K, Kobayashi Y, Kiuchi T. Current status of living donor liver transplantation in adults. Curr Opin Organ Transpl. 2000;5:74-80.

[109] Adam R, McMaster P, O'Grady JG, Castaing D, Klempnauer JL, Jamieson N, et al. Evolution of liver transplantation in Europe: report of the European Liver Transplant Registry. Liver Transpl. 2003 Dec;9(12):1231-43.

[110] Data from US transplant organization. Available at: http:// www.ustransplant.org/index.php. Accessed on March 27. 2004.

[111] The Japanese Liver Transplantation Society. Liver Transplantation in Japan. Registery by the Japanese Liver Transplantation Society [Japanese]. Jpn J Transpalnt. 2004;38:401-8. 
[112] Lo CM, Fan ST, Liu CL, Chan JK, Lam BK, Lau GK, et al. Minimum graft size for successful living donor liver transplantation. Transplantation. 1999 Oct 27;68(8):1112-6.

[113] Fan ST, Lo CM, Liu CL, Yong BH, Chan JK, Ng IO. Safety of donors in live donor liver transplantation using right lobe grafts. Arch Surg. 2000 Mar;135(3):336-40.

[114] Urata K, Kawasaki S, Matsunami H, Hashikura Y, Ikegami T, Ishizone S, et al. Calculation of child and adult standard liver volume for liver transplantation. Hepatology. 1995 May;21(5):1317-21.

[115] Sugawara Y, Makuuchi M, Kaneko J, Kokudo N. MELD score for selection of patients to receive a left liver graft. Transplantation. 2003 Feb 27;75(4):573-4.

[116] Wiesner RH, McDiarmid SV, Kamath PS, Edwards EB, Malinchoc M, Kremers WK, et al. MELD and PELD: application of survival models to liver allocation. Liver Transpl. 2001 Jul;7(7):567-80.

[117] Inomata Y, Uemoto S, Asonuma K, Egawa H. Right lobe graft in living donor liver transplantation. Transplantation. 2000 Jan 27;69(2):258-64.

[118] Wachs ME, Bak TE, Karrer FM, Everson GT, Shrestha R, Trouillot TE, et al. Adult living donor liver transplantation using a right hepatic lobe. Transplantation. 1998 Nov 27;66(10):1313-6.

[119] Bak T, Wachs M, Trotter J, Everson G, Trouillot T, Kugelmas M, et al. Adult-to-adult living donor liver transplantation using right-lobe grafts: results and lessons learned from a single-center experience. Liver Transpl. 2001 Aug;7(8):680-6.

[120] Lo CM, Fan ST, Liu CL, Lai CL, Wong J. Prophylaxis and treatment of recurrent hepatitis B after liver transplantation. Transplantation. 2003 Feb 15;75(3 Suppl):S414.

[121] Lee S, Park K, Hwang S, Lee Y, Choi D, Kim K, et al. Congestion of right liver graft in living donor liver transplantation. Transplantation. 2001 Mar 27;71(6):812-4.

[122] Gyu Lee S, Min Park K, Hwang S, Hun Kim K, Nak Choi D, Hyung Joo S, et al. Modified right liver graft from a living donor to prevent congestion. Transplantation. 2002 Jul 15;74(1):54-9.

[123] Leelaudomlipi S, Sugawara Y, Kaneko J, Matsui Y, Ohkubo T, Makuuchi M. Volumetric analysis of liver segments in 155 living donors. Liver Transpl. 2002 Jul;8(7):612-4.

[124] Sugawara Y, Makuuchi M, Takayama T, Mizuta K, Kawarasaki H, Imamura H, et al. Liver transplantation using a right lateral sector graft from a living donor to her granddaughter. Hepatogastroenterology. 2001 Jan-Feb;48(37):261-3.

[125] Sugawara Y, Makuuchi M, Takayama T, Imamura H, Kaneko J. Right lateral sector graft in adult living-related liver transplantation. Transplantation. 2002 Jan 15;73(1):111-4.

[126] Lee S, Hwang S, Park K, Lee Y, Choi D, Ahn C, et al. An adult-to-adult living donor liver transplant using dual left lobe grafts. Surgery. 2001 May;129(5):647-50.

[127] Lee SG, Hwang S, Park KM, Kim KH, Ahn CS, Lee YJ, et al. Seventeen adult-to-adult living donor liver transplantations using dual grafts. Transplant Proc. 2001 NovDec;33(7-8):3461-3.

[128] Horslen SP, Fox IJ. Hepatocyte transplantation. Transplantation. 2004 May 27;77(10):1481-6.

[129] Strom SC, Chowdhury JR, Fox IJ. Hepatocyte transplantation for the treatment of human disease. Semin Liver Dis. 1999;19(1):39-48. 
[130] Shafritz DA, Dabeva MD. Liver stem cells and model systems for liver repopulation. Journal of hepatology. 2002 Apr;36(4):552-64.

[131] Gupta S. Hepatocyte transplantation. J Gastroenterol Hepatol. 2002 Dec;17 Suppl 3:S287-93.

[132] Fox IJ, Roy-Chowdhury J. Hepatocyte transplantation. Journal of hepatology. 2004 Jun;40(6):878-86.

[133] Afzelius BA, Schoental R. The ultrastructure of the enlarged hepatocytes induced in rats with a single oral dose of retrorsine, a pyrrolizidine (Senecio) alkaloid. J Ultrastruct Res. 1967 Oct 31;20(5):328-45.

[134] Mito M, Kusano M, Kawaura Y. Hepatocyte transplantation in man. Transplant Proc. 1992 Dec;24(6):3052-3.

[135] Arkadopoulos N, Chen SC, Khalili TM, Detry O, Hewitt WR, Lilja H, et al. Transplantation of hepatocytes for prevention of intracranial hypertension in pigs with ischemic liver failure. Cell Transplant. 1998 Jul-Aug;7(4):357-63.

[136] Nagata H, Ito M, Shirota C, Edge A, McCowan TC, Fox IJ. Route of hepatocyte delivery affects hepatocyte engraftment in the spleen. Transplantation. 2003 Aug 27;76(4):732-4.

[137] Mito M, Kusano M, Onishi T, Saito T, Ebata H. Hepatocellular transplantation -morphological study on hepatocytes transplanted into rat spleen. Gastroenterol Jpn. 1978;13(6):480-90.

[138] Ito M, Nagata H, Yamamoto T, Yoshihara D, Fox IJ, Miyakawa S. Intrasplenic hepatocyte transplantation prolonged the survival in Nagase analbuminemic rats with liver failure induced by common bile duct ligation. Cell Transplant. 2007;16(5):547-53.

[139] Kobayashi N, Ito M, Nakamura J, Cai J, Hammel JM, Fox IJ. Treatment of carbon tetrachloride and phenobarbital-induced chronic liver failure with intrasplenic hepatocyte transplantation. Cell Transplant. 2000 Sep-Oct;9(5):671-3.

[140] Makowka L, Rotstein LE, Falk RE, Falk JA, Langer B, Nossal NA, et al. Reversal of toxic and anoxic induced hepatic failure by syngeneic, allogeneic, and xenogeneic hepatocyte transplantation. Surgery. 1980 Aug;88(2):244-53.

[141] Platt JL. New directions for organ transplantation. Nature. 1998 Apr 30;392(6679 Suppl):11-7.

[142] Nagata H, Ito M, Cai J, Edge AS, Platt JL, Fox IJ. Treatment of cirrhosis and liver failure in rats by hepatocyte xenotransplantation. Gastroenterology. 2003 Feb;124(2):42231.

[143] Ramirez P, Chavez R, Majado M, Munitiz V, Munoz A, Hernandez Q, et al. Lifesupporting human complement regulator decay accelerating factor transgenic pig liver xenograft maintains the metabolic function and coagulation in the nonhuman primate for up to 8 days. Transplantation. 2000 Oct 15;70(7):989-98.

[144] Zhang Y, Riesterer C, Ayrall AM, Sablitzky F, Littlewood TD, Reth M. Inducible sitedirected recombination in mouse embryonic stem cells. Nucleic Acids Res. 1996 Feb 15;24(4):543-8. 


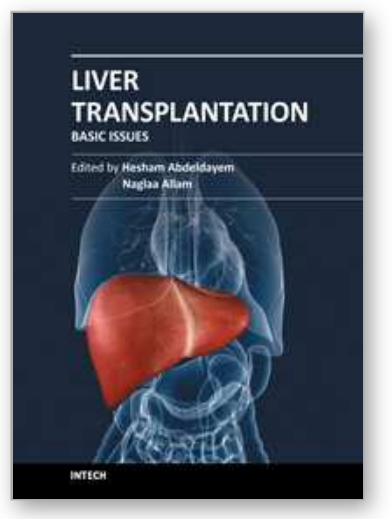

\author{
Liver Transplantation - Basic Issues \\ Edited by Prof. Hesham Abdeldayem
}

ISBN 978-953-51-0016-4

Hard cover, 418 pages

Publisher InTech

Published online 15, February, 2012

Published in print edition February, 2012

This book covers a wide spectrum of topics including history of liver transplantation, ischemia-reperfusion injury, immunology of liver transplantation, viral hepatitis and liver transplantation, other indications for liver transplantation, prognostic factors and perioperative period. The authors of the chapters are experts in their respective fields. They are proponents covering different aspects of liver transplantation and come from many centers across the world. The interdisciplinary approach and the authority of the contributors resulted in a valuable reference to anyone interested in developing a global view in liver transplantation including medical students, residents, fellows, nurses, and practicing physicians and surgeons as well as researchers in the field of liver transplantation.

\title{
How to reference
}

In order to correctly reference this scholarly work, feel free to copy and paste the following:

Ayman Azzam (2012). History and Evolution of Liver Transplantation, Liver Transplantation - Basic Issues, Prof. Hesham Abdeldayem (Ed.), ISBN: 978-953-51-0016-4, InTech, Available from: http://www.intechopen.com/books/liver-transplantation-basic-issues/history-and-evolution-of-livertransplantation

\section{INTECH}

open science | open minds

\section{InTech Europe}

University Campus STeP Ri Slavka Krautzeka 83/A 51000 Rijeka, Croatia Phone: +385 (51) 770447 Fax: +385 (51) 686166 www.intechopen.com

\section{InTech China}

Unit 405, Office Block, Hotel Equatorial Shanghai No.65, Yan An Road (West), Shanghai, 200040, China 中国上海市延安西路65号上海国际贵都大饭店办公楼405单元 Phone: +86-21-62489820

Fax: +86-21-62489821 
(C) 2012 The Author(s). Licensee IntechOpen. This is an open access article distributed under the terms of the Creative Commons Attribution 3.0 License, which permits unrestricted use, distribution, and reproduction in any medium, provided the original work is properly cited. 